\title{
REFERENCES
}

Alkins, w. E. I922. Two molluscan associations in north-east Staffs. F. Conch., I6 (9), 29 I-296.

вочсотт, A. E. 1934. The habitats of land mollusca in Britain. F. Ecol., 22, г-38. cain, A. J., And sheppard, P. M. 1954. Natural selection in Cepaea. Genetics, 39, 89-I I 6.

CARTWRIGHT, w. I922. On the association and non-association of Helix nemoralis Linne and Helix hortensis Müller. F. Conch., I6 (10), 313-318.

Dalgliesh, J. G. I930. Field notes on Cepaea nemoralis Linn. and Cepaea hortensis Müller, in Sussex. 7. Conch., 19 (3), 94-96.

DIVER, c. 1940. The problem of closely related species living in the same area. Pp. 303-328 in The New Systematics, ed. J. S. Huxley, Oxford University Press.

LOWE, R. H. I944. The mollusca of Leyburn and district. F. Conch., 22 (4), 87-9I. oldham, C. I929. Cepaea hortensis (Mueller) and Arianta arbustorum (L.) on blown sand. Proc. Malac. Soc. Lond., 18 , I 44-1 46.

StRatton, L. w. 1950. The land mollusca of the parish of Aldenham: A re-survey. Trans. Herts. Nat. Hist. Soc., I3, Ioo-1 27.

\section{DURATION OF MEIOSIS IN RELATION TO TEMPERATURE}

\author{
J. YANNEY WILSON * \\ Department of Botany, Universitv College, Achimota, Ghana
}

Received x.x.58

\section{INTRODUCTION}

Knowledge of the time taken by meiosis is rather fragmentary and is sometimes given without specifying the temperature. The following examples of published data on the duration of meiosis illustrate this: Lilium longiflorum and Gasteria, 4 days (Marquardt, I937; Straub, I937); Vicia faba, 3 to 4 days (Marquardt, 195I) ; Antirrhinum majus, from the last premeiotic mitosis to tetrad, 30 to 34 hours (Ernst, 1938); Tradescantia reflexa, at room temperature, 18 to $23^{\circ} \mathrm{C} ., 2$ days (Sax and Edmonds, I953); T. paludosa, at an unspecified room temperature, $5^{2}$ hours (Steinitz, 1944); CEnothera at $10^{\circ}$ C., 12 days, but from leptotene to metaphase I, only 6 days (Linnert, 195I). No attempt seems to have been made to determine the times taken by meiosis in the same organism over a wide range of temperatures. On the other hand, in mitosis Barber (1939) studied the rate of chromosome movement at anaphase in staminal hairs of Tradescantia at various temperatures, and much fuller data on plant and animal material have been provided by Hughes (1952). Brown (I95I) determined the duration of various stages of cell division in root tips of Pisum at the temperatures of $15,20,25$ and $30^{\circ} \mathrm{C}$.

In the present paper an account is given of an attempt to determine the rate of complete meiosis (not the various stages) in pollen mother-cells of the Bluebell, Endymion nonscriptus (L.) Garcke at different temperatures, and to compare this with the rate of mitosis.

* Formerly of the Botany School, University of Cambridge. 


\section{EXPERIMENTAL PROCEDURE}

The material came from Madingley Wood, Cambridge, during the wintcr of 1955-56. In Endymion nonscriptus the outermost anther, with respect to the horal axis, is commonly the most advanced in development but is generally closely followed in clockwise scquence (secn from above) by the other two outer anthers and the three inner ones in the same fashion (fig. 1). The differences between the age of the thrce outer anthers were small and were regarded for the present study as negligible. But there was a much more significant difference between the age of the youngest of the outer anthers and the oldest of the inner anthers. The latter were not used in the experiments.

After removing the upper half of the scalcs of a bulb to expose

0

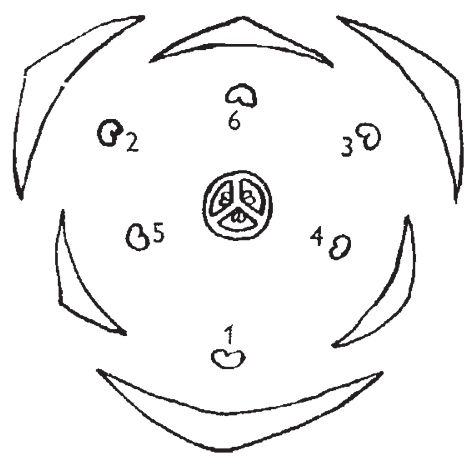

F1G, 1.-Floral diagram showing the usual (clockwise) order of progression of meiosis within the anthers of a flower-bud in the Bluebell. (Oldest and out ermost anther is numbercd 1 ; youngest and innermost anther, 6 .) the inflorescence, the outermost anther in the lowest flower-bud was removed and its meiotic stage detcrmined in an aceto-carmine smear. If this anther showed an early stage of meiosis, then the inflorescence (with the stcm and roots of the bulb still attached to it) was labelled and placed on a pad of wet cotton-wool in a petri-dish and covered with a similar pad in the lid. Bulbs prepared in this way were kept in constant-temperature chambers at $-5^{\circ} \mathrm{C}$., $-3^{\circ} \mathrm{C}$., $0^{\circ} \mathrm{C}$. and at intervals of $5^{\circ}$ to $35^{\circ} \mathrm{C}$. Others were kept at room temperature $\left(15-2 \mathrm{I}^{\circ} \mathrm{C}\right.$. $)$. The plants werc regularly watered through the cotton-wool, using watcr storcd at the appropriate temperatures. At intervals the other two outer anthers in the bud were removed, examined as above, and the meiotic stage reached recorded.

\section{EXPERIMENTAL RESULTS}

No results were obtained at $-5,-3$ and $+35^{\circ} \mathrm{C}$., since at these temperatures the plants died before full meiosis was completed. The results for the remaining temperatures are sct out in table $\mathbf{I}$. It is evident that the time taken from leptotene to metaphase $I$ is about half the time taken for the whole of meiosis.

The duration of meiosis (Leptotene to Tetrad) at the various temperatures is as follows :

\begin{tabular}{|c|c|c|c|c|c|c|c|}
\hline Temrperature ${ }^{\circ} \mathrm{C}$. & $0^{\circ}$ & $5^{\circ}$ & $10^{\circ}$ & $15^{\circ}$ & $20^{\circ}$ & $95^{\circ}$ & $30^{\circ}$ \\
\hline $\begin{array}{c}\text { Time in Days } \\
(24 \text { hrs. })\end{array}$ & 36.00 & $15^{\circ} 00$ & $7^{\circ} 00$ & $3.5^{\circ}$ & $2 \cdot 00$ & $1 \cdot 25$ & 0.83 \\
\hline
\end{tabular}

At room temperature $\left(15^{-2} 1^{\circ}\right.$ C. $)$ meiosis took $2 \cdot 75$ days. 
TABLE I

Determinations of time taken by meiosis at different temperatures

\begin{tabular}{|c|c|c|c|c|c|c|c|}
\hline $\begin{array}{c}\text { Plant } \\
\text { no. }\end{array}$ & $\begin{array}{l}\text { Original } \\
\text { stage }\end{array}$ & $\begin{array}{l}\text { Time } \\
\text { in days }\end{array}$ & Final stage & $\begin{array}{l}\text { Plant } \\
\text { no. }\end{array}$ & $\begin{array}{l}\text { Original } \\
\text { stage }\end{array}$ & $\begin{array}{l}\text { Time } \\
\text { in days }\end{array}$ & Final stage \\
\hline \multicolumn{4}{|c|}{$0^{\circ} \mathrm{C}$. } & \multicolumn{4}{|c|}{$5^{\circ} \mathrm{C}}$. \\
\hline I & Lept. & 7 & \multirow{9}{*}{$\begin{array}{l}\text { Pach. } \\
\text { Pach. } \\
\text { Tetrad } \\
\text { Met. I } \\
\text { Anaph. I } \\
\text { Met. I } \\
\text { Met. + } \\
\text { Anaph. I } \\
\text { Tetrad } \\
\text { Tetrad }\end{array}$} & I & Lept. & IO & \multirow{7}{*}{$\begin{array}{l}\text { Diak. } \\
\text { Met. I } \\
\text { Diak. } \\
\text { Anaph. I } \\
\text { Pach. } \\
\text { Tetrad } \\
\text { Tetrad }\end{array}$} \\
\hline 2 & Lept. & IO & & 2 & Lept. & IO & \\
\hline 3 & Met. I & $2 \mathrm{I}$ & & 3 & Lept. & I I & \\
\hline 4 & Lcpt. & 20 & & 4 & Lept. & 12 & \\
\hline 5 & Lept. & 24 & & 5 & Lept. & 6 & \\
\hline 6 & Lept. & 20 & & 6 & Dipl. & 9 & \\
\hline 7 & Lept. & 22 & & 7 & Lept. & I 6 & \\
\hline 8 & Lept. & $3^{6}$ & & \multirow[t]{2}{*}{8} & \multirow[t]{2}{*}{ Lept. } & 14 & \multirow[t]{2}{*}{ Tetrad } \\
\hline 9 & Lept. & $3^{6}$ & & & & & \\
\hline \multicolumn{4}{|c|}{$10^{\circ} \mathrm{C}$} & \multicolumn{4}{|c|}{$15^{\circ} \mathrm{C}$. } \\
\hline I & Lept. & 5 & Anaph. I & I & Lept. & $I \cdot 5$ & Met. I \\
\hline 2 & Lept. & 4 & Met. I & 2 & Lept. & 2 & Tet. I \\
\hline 3 & Lept. & $\frac{1}{6}$ & Met. II & 3 & Met. I & 2 & Met. II \\
\hline 4 & Diak. & 5 & Anaph. II & 4 & Lept. & $I \cdot 5$ & Diak. \\
\hline 5 & Lept. & $3 \cdot 5$ & Met. I & 5 & Met. I & $2^{3}$ & Anaph. II \\
\hline 6 & Lept. & $7 \cdot 0$ & Tetrad & 6 & Lept. & $3 \cdot 5$ & Tetrad \\
\hline 7 & Lept. & $7 \cdot 0$ & Tetrad & 7 & Iept. & $3 \cdot 5$ & Tetrad \\
\hline \multicolumn{4}{|c|}{$20^{\circ} \mathrm{C}$} & \multicolumn{4}{|c|}{$25^{\circ} \mathrm{C}$} \\
\hline I & Lept. & 2 & Met. II & I & Lept. & 24 & \multirow{7}{*}{$\begin{array}{l}\text { Tet. I } \\
\text { Anaph. II } \\
\text { Tetrad } \\
\text { Anaph. I } \\
\text { Met. I } \\
\text { Tetrad } \\
\text { Tetrad }\end{array}$} \\
\hline 2 & Lept. & 3 & Tetrad & 2 & Lept. & 26 & \\
\hline 3 & Lept. & I & Met. I & 3 & Anaph. I & IO & \\
\hline 4 & Diak. & $I \cdot 5$ & Anaph. II & 4 & Lept. & 20 & \\
\hline 5 & Diak. & $I \cdot 5$ & Tet. I & 5 & Lept. & I 5 & \\
\hline 6 & Lept. & $2 \cdot 00$ & Tetrad & 6 & Lept. & 30 & \\
\hline 7 & Lept. & $2 \cdot 00$ & Tetrad & 7 & Lept. & 30 & \\
\hline \multicolumn{4}{|c|}{$30^{\circ} \mathrm{C}$} & \multicolumn{4}{|c|}{ Room I 5-2 I ${ }^{\circ} \mathrm{C}$. } \\
\hline I & Lept. & $3^{6}$ & (Destroyed) & I & Lept. & 2 & Anaph. I \\
\hline 2 & Lept. & 24 & (Destroyed) & 2 & Dipl. & 2 & Tet. I \\
\hline 3 & Lept. & 20 & Tetrad & 3 & Pach. & I & Met. I \\
\hline 4 & Lept. & 6 & Dipl. & 4 & Diak. & 2 & Anaph. II \\
\hline 5 & Lept. & I 2 & Anaph. I & 5 & Dipl. & 2 & Anaph. II \\
\hline 6 & Lept. & 20 & 'Tetrad & 6 & Dipl. & $\mathrm{I} \cdot 75$ & Met. II \\
\hline 7 & Lept. & 20 & Tetrad & 7 & Met. & $I \cdot 75$ & Anaph. II \\
\hline & & & & 8 & Lept. & $2 \cdot 75$ & Tetrad \\
\hline & & & & 9 & Lept. & $2 \cdot 75$ & Tetrad \\
\hline
\end{tabular}




\section{DISCUSSION}

The data obtained on the duration of meiosis in Endymion nonscriptus at various temperatures agree broadly with the published results given above. Similar studies with other material would be interesting for comparison.

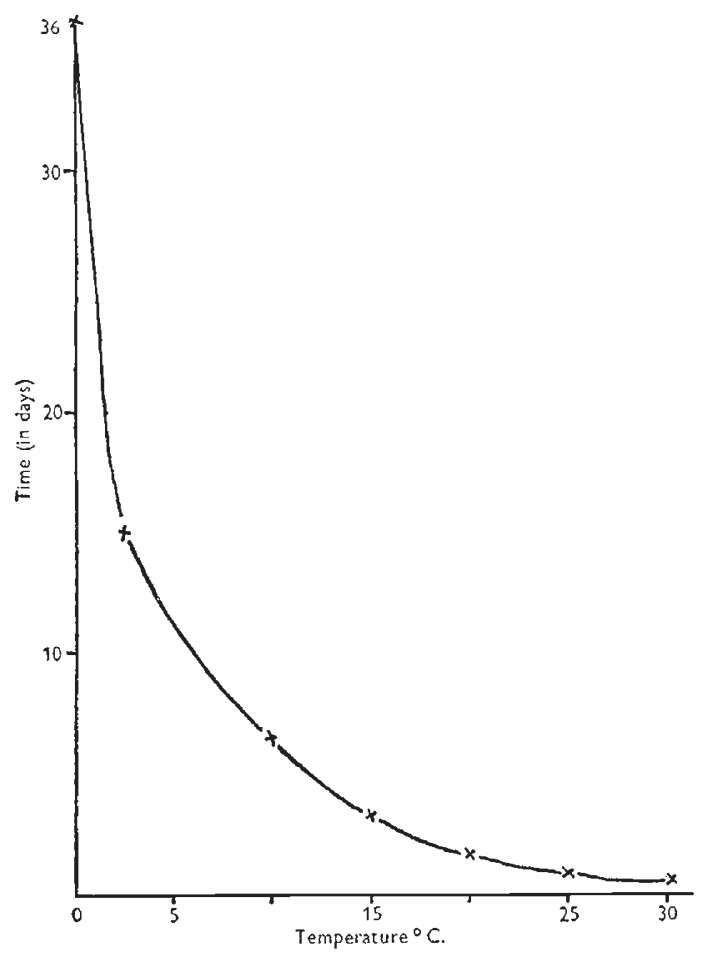

F1G. 2.-Graph showing the effect of temperature in accelerating the time taken by meiosis in the Bluebell.

A great acceleration in the rate of meiosis with increasing temperature is evident (fig. 2). $Q_{10}$ values mcasured at $5^{\circ}$ intervals (see Barbcr (1939) for method of calculation) are given below :

\begin{tabular}{|c|c|c|c|c|}
\hline Temperatures ${ }^{\circ} \mathrm{C}$. & Q5 & $\log$ & $\mathrm{X}_{2}$ & $Q_{10}$ \\
\hline $0-5^{\circ}$ & $2 \cdot 4000$ & 0.3802 & $0 \cdot 7604$ & 5.759 \\
\hline $5-10^{\circ}$ & $2 \cdot 1428$ & $0 \cdot 3308$ & 0.6616 & 4.588 \\
\hline $10-15^{\circ}$ & $2 \cdot 0000$ & $0 \cdot 3010$ & $0 \cdot 6020$ & 3.999 \\
\hline I $5-20^{\circ}$ & $1 \cdot 7500$ & $0 \cdot 2430$ & 0.4860 & 3.062 \\
\hline $20-25^{\circ}$ & $1 \cdot 6000$ & $0 \cdot 2041$ & 0.4082 & $2 \cdot 560$ \\
\hline $25-30^{\circ}$ & $I \cdot 5060$ & $0.176 \mathrm{r}$ & 0.3522 & 2.250 \\
\hline
\end{tabular}

These results are comparable to those for respiration in plant tissues, where $Q_{10}$ values of 2.0 to 2.5 are usual within the range of $10^{\circ} \mathrm{C}$. to $30^{\circ} \mathrm{C}$., and with higher values at temperatures below $10^{\circ} \mathrm{C}$. (Meyer and Anderson, 1952). Brown (1951) found that the mean duration of mitosis in Pisum at various temperatures was as follows: $15^{\circ}$ C., 2.95 hours; 
$20^{\circ}, 1 \cdot 83$ hours ; $25^{\circ}, 1 \cdot 38$ hours; and $30^{\circ} \mathrm{C}$., $1 \cdot 09$ hours. Thus, meiosis in Endymion anthers takes about 20 times as long as mitosis in Pisum at the same temperature. The $Q_{10}$ values for the rate of mitosis from Brown's data, calculated in the same way as above, are : $15^{-20^{\circ}}, 2.59^{8} ; 20-25^{\circ}$, $1 \cdot 75^{8}$; and $25-30^{\circ}, 1 \cdot 606$. It is thus clear that, while in both meiosis and mitosis $Q_{10}$ values fall with increasing temperature, the values are relatively lower in mitosis.

\section{SUMMARY}

I. The duration of meiosis in the pollen mother-cells of the Bluebell, Endymion nonscriptus (L.) Garcke, has been estimated for various temperatures ranging from $0^{\circ} \mathrm{C}$. to $30^{\circ} \mathrm{C}$.

2. Meiosis showed a rapid shortening of duration with increasing temperature, but the $Q_{10}$ values fall as the temperature rises.

3. Meiosis in the Bluebell lasted about 20 times as long as mitosis in Pisum at the same temperature (data of Brown (1951)).

Acknowledgments.-The author is indebted to Dr H. L. K. Whitehouse and the authorities of the Botany School and the Low Temperature Research Station, Cambridge, for their help in advice and facilities.

\section{REFERENCES}

BARBER, H. N. I939. The rate of chromosome movement on the spindle. Chromosoma, $I, 33$.

BROWN, R. I951. Effects of temperature on durations of different stages of celldivision in root-tips. 7. Exp. Bot., 2, 96-1 Io.

ERNST, H. 1938. Meiosis und Crossing-over. Zytologische und genetische Untersuchungen an Antirrhinum majus L. Zeit. f. Bot., 33, 241-294.

Hughes, A. 1952. The Mitotic Cycle. Butterworth's Scientific Publications, London. Linnert, G. I95 I. Die Einwirkung von Chemikalien auf die Meiosis. Zeit.f. ind. Abs. und Vererbgs., $83,422-428$.

Marquardt, H. 1937. Die Meiosis von Oenothera I. Zeit.f. Zellforsch., 27, i 59-2 Io. MARQUARDT, H. I95I. Die Wirkung der Röntgenstrahlen auf die Chiasma frequenz in der Meiosis von Vicia faba. Chromosoma, 4, 232-238.

meyer, B. S., ANd Anderson, D. B. 1952. Plant Physiology. 2nd ed., New York.

SAX, K., AND EDMONDS, H. W. 1953. Development of the male gametophyte in Tradescantia. Bot. Gaz., 95, i 56-163.

Steinitz, L. M. I944. The effect of lack of oxygen on meiosis in Tradescantia. Amer. Fourn. Bot., 3I, 428-443.

Straub, J. 1937. Untersuchungen zur Physiologie der Meiosis, VII. Ebenda, 32, 225-268. 